\title{
Public administration reform in Eritrea: Past trends and emerging challenges
}

\author{
GebreMichael Kibreab Habtom \\ College of Business and Economics, University of Asmara, Eritrea. \\ Received 6 May, 2014; Accepted 18 August, 2014
}

\begin{abstract}
Public administration has always been the tool available to African governments for the implementation of developmental goals and objectives. It is seen as being crucial to the growth and development of African economies. To this end efforts have been made in many African countries to increase efficiency through decentralization, restructuring and privatization. This study presents Eritrea's public administration reform experience, and assesses the extent to which Eritrea has taken up New Public Management reforms. The aim is to show the outcome of reforms on civil service, public enterprises and local government management. It is found that in Eritrea there is a need for periodic review and continuous administrative reform. In the civil service there are absence of promotion, retirement, and lack of competitive wages and salary increments. In local government there are lack of administrative capacity, absence of clear accountability lines and fiscal decentralization, and lack of coordination and information sharing among local government units and line ministries. The Eritrean government should now emphasize on investment in developing human capital towards effective policy formulation, analysis, implementation and evaluation, and on the reform of the public sector itself besides privatization aimed at allowing public enterprises to operate more efficiently and effectively.
\end{abstract}

Key words: Eritrea, reform, public administration, local government, civil service, public enterprises.

\section{INTRODUCTION}

Eritrea ${ }^{1}$, being the youngest African nation, became a sovereign nation in 1993. Since 1993, Eritrea has

${ }^{1}$ Eritrea is an East African country, which is bordered with Ethiopia in the south, with Sudan in the north and the west, with Djibouti in the southeast, and with the Red Sea in the east. Eritrea got independence from Ethiopia in 1993 after 30 years of armed struggle. Eritrea's population is estimated to be 5.2 million, with an average life expectancy of 60.4 years and a literacy rate of 67.5 percent (UNDP Report, 2009). The population pyramid follows an early development pattern: $43 \%$ of the population is under 15 years old, $6 \%$ above 65 years old and nearly $70 \%$ of the population is composed of children and women in child-bearing age (Haddas Eritrea, 2002; World Bank, 2000). About $52 \%$ of the Eritrean population is under 18 years old and $17 \%$ are under five years old (UNICEF, 2004). 80\% of the people live in rural areas, and the population density ranges from 36.3 to 40.6 people per sq. km (World Bank, 2002). Agriculture is the main stay of the Eritrean economy whereby $80 \%$ of the population depends for its livelihood. About 30\% of Eritreans are semi- embarked on a multifaceted nation-building and reconstruction process in which the civil service is one aspect. The critical challenge that faces Eritrea today is the establishment of economic, social, administrative and political institutions and the development and utilization of human resources to enable these institutions to operate effectively (Gafer, 1996; Haregot et al., 1993; UNDP, 2002; UOA, 1997). Eritrea, as a new nation, is confronted by three challenges of transition: a transition from a state dominated economic order to market based economic system; a transition from colonial military regime to a just

nomadic or agro-pastoralists. For the year 2010, the GDP for Eritrea was estimated at US\$3.625 billion together with a per capita estimate of US\$681 (World Bank, 2010). 
and democratic society; and a transition from conflicts and strife to political reconciliation and economic rehabilitation. These transitional challenges demand for civil service, public enterprises and local government reforms.

Eritrea inherited obsolete institutions and weak instruments for managing its economic policies. The inherited colonial bureaucracy was inefficient and characterized by a corrupt nature of administrative infrastructures. It had many attributes that render it unsuitable for many challenges of the Eritrean government. It was filled by administrators without adequate professional qualifications, excessively dependent on seniority rather than merit considerations with negative implication for moral and efficiency. It remains also both understaffed and overstaffed. It was significantly understaffed in professional and managerial areas and overstaffed in semi-skilled and unskilled areas. The inherited public enterprises have been also accused of wasting resources and operating inefficiency with low profitability or even financial difficulties. They were over centralized, undercapitalized and supervised under a regime of controlled prices. Under Ethiopian rule the Eritrean provincial administration had little autonomy and policy making capacity, as the result provincial government officials had little technical and managerial capacity to co-ordinate and supervise the overall planning and implementation of governmental functions. Many community leaders in Eritrea are also not in a position to lead the needed transformation and to take charge of the subsequent change in working out procedures the new technology require and induce due to the educational gap and unfamiliarity (UN, 2001).

Since 1995 Eritrea has been conducting civil service, public enterprises and local government reforms. These reforms were triggered by the quest for efficient and effective public administration influenced by the Structural Adjustment Programs (SAPs) and New Public Management (NPM) movements of the 1980s. In this paper, therefore, we intend to assess public administration reforms in Eritrea (past trends and emerging challenges). The paper reviews also public sector reform experience in African. The aim is to show how such experiences can help Eritrea to improve the content and approach to public administration reforms. In this study three broad sets of questions are addressed: (1) How were the various public administration reforms (civil service, local government and public enterprises) initiated in Eritrea to improve state capacity and what were their outcomes? (2) How effective were the strategies implemented to promote accountability and minimize corruption? And (3) what are the possible policy options for the future and how relevant are they in addressing the challenges facing public administration?

\section{REVIEW OF RELATED LITERATURE}

Public Administration Reform can be very comprehensive and include process changes in areas such as organizational structures, decentralization, personnel management, public finance, results-based management, regulatory reforms etc (UNDP, 2004). Cited in Ayee (2008), Turner and Hulme (1997), Peters (1992), Dror (1976), and Caiden $(1978,1991)$ have identified a number of strategies that have been employed in administrative reform. These are administrative restructuring, decentralization, enhancing accountability measures, public-private partnership, privatization, contracting out, streamlining, downsizing, etc. These strategies are associated with the New Public Management (NPM) perspective, which often focused on positive, actionoriented phrases such as: reinventing government, reengineering, revitalization of the public service, organizational transformation, total quality management, paradigm shift, entrepreneurship, empowerment, resultsover process, downsizing-and 'rightsizing', lean and mean, contracting out, offloading or outsourcing, steering rather than rowing, empowering rather than serving, and earning rather than spending (Frederickson, 1996).

In developing countries public administration reform derives from three main intellectual threads (UNDP, 2004: 2-3):

a). New public management - the NPM seeks to roll back the role of the state by applying private sector management principles to government organizations. A number of Anglo-Saxon countries (the UK, New Zealand, Australia, the United States and Canada) starting in the early 1980s, began implementing wide ranging reform programs that provided both the model and the experience that could be applied in developing countries. The relevance of the NPM to public sector management can be found in four main areas: (i) decentralizing management, disaggregating and downsizing of public services; (ii) performance contracting, which has become an instrument to reform state-owned enterprises (SOEs); (iii) contracting out of the provision of public services is part of efforts to reconfigure state-market relations in order to give more prominence to markets and the private sector; and (iv) the introduction of user fees or charges, which is one of the major developments in the provision

E-mail: g mic haelkibreab@g ma il.com.

Author agree that this article remain permanently open access under the terms of the Creative Commons Attribution Lic ense 4.0 Intemational Lic ense 
of public services under structural adjustments programs (SAPs) if privatization is not being pursued (Ayee, 2005). NPM shifts the emphasis from traditional public admini-stration to public management, and pushes the state towards managerialism. The traditional model of organization and delivery of public services, based on the principles of bureaucratic hierarchy, planning, centralization, direct control and self-sufficiency, is replaced by a market-based public service management or 'enterprise culture' (Larbi 1999; Walsh 1995; Hood 1991; cited in Ayee, 2005).

b). Structural adjustment reforms -- in the mid 1980s, efforts at reforming the public administration in developing countries, supported by the international financial institutions, focused on reducing overall costs of the government, mainly through privatisation of state owned enterprises and reduction of the wage bill to bring government spending down to sustainable levels and free resources for other uses more beneficial to the overall economy, devaluation of currencies so that exports will be cheaper to foreign buyers, quit setting of agricultural prices and elimination of subsidies to urban consumers, ending import restrictions and increasing bank interest rates to encourage savings to generate capital investment (Ayee, 2008; Gordon, 1992).

c). Transition from central planning to market economy and from single party systems to multi-party democracies (Beyene and Otobo, 1994). The fall of the Soviet Union has persuaded governments of previously socialist countries to transform their economies to adhere more to market principles often linked to political reforms. In the 1990s, a large number of economies, especially in Central and Eastern Europe (but also in countries in South-East Asia) began this transition. This implied the reorientation of the system of public administration.

Since the early 1980s, significant efforts have been made in Africa toward the reform and transformation of public service management ${ }^{2}$. Those efforts have been driven primarily by the fact that state bureaucracies in Africa under perform; are invariably too large and corrupt; and lack a sense of responsibility and accountability (Hope, 1997, 2001; Hope and Chikulo, 1999). These reforms sought to reduce the role of the state in production as well as service delivery and encourage the deregulation of public enterprises. The state is expected to provide an enabling environment for private sector economic activities by implementing appropriate economic policy reforms and providing the necessary legal and regulatory framework. It is also expected to provide some of the social and physical infrastructure, sometimes in

\footnotetext{
${ }^{2}$ Public sector reform in Africa is divided into three phases, namely, (1) the reforms from the 1980s to early 1990s, which focused mainly on macroeconomic stability and were mainly "quantitative"; (2) the reforms of the mid1990s to 2000, which focused on performance and civil service management; and (3) reforms from 2000, which focused on service delivery (Ayee, 2008).
}

partnership with community based organizations. The emphasis was on maintaining macro economic stability, lowering inflation, cutting deficit spending, and reducing the scope and cost of government (Ayee, 2008). Yet these new roles for the state are not necessarily easier and in many respects may be beyond the capacity of many developing country governments.

However, the outcome of structural adjustment in African countries was not encouraging, because the reform depended on ready markets for exports and substantial investments from industrial countries, which, for the most part, were not substantiated (Ayee, 2008). Devaluation of currencies in many African countries lead in to inflation and thriving black markets, on the other hand, freezing of government salaries resulted loosing of competent government employees because they move to private and non-government organizations at a higher salary. Poor pay for managers frequently impedes recruitment and performance. It is estimated that in Anglophone Africa, public sector wages declined $80 \%$ in real terms between the early1970s and 1980s (paralleling the general decline in GDP per capita) (Van de Walle, 2001: 134). During this period therefore the now familiar problems of moonlighting and absenteeism, low morale, corruption and politicization of recruitment emerged (ECA, 2010). There is little doubt that in many countries the capacity of ministries including finance ministries to fulfill even basic tasks virtually collapsed.

The reforms related to the functioning and role of the state in the economic sphere have, in some countries produced positive results. For instance, public management reforms in Botswana produced successive development plans. Some of the reforms include the adoption of the performance management system, work improvement teams, computerized personnel management system, organization and methods reviews, performance based reward system and decentralization (ECA, 2010). Ministries and departments were rationalized in order to improve efficiency and effectiveness in service delivery and autonomous authorities were established to work largely on commercial principles (ADB 2005; Olaopa 2009, cited in ECA, 2010). A key thing to note is that the reforms, unlike in most African countries, have largely been driven by a succession of competent leadership and dedicated workforce who are committed to continuous administrative reform. Local government reforms also produced positive results in South Africa, Uganda and Ethiopia. In South Africa and Uganda, decentralization has been regarded as a way of re-unifying their countries (World Bank, 1999). In South Africa, decentralization reversed the dual system of government based on race and the limited access to public goods and services in the "homelands" and "townships" (Ayee, 2005). In Ethiopia decentralization is used as an instrument for deflating secessionist tendencies. The transformational leadership good practices have also been recorded in Ghana, 
Liberia and Rwanda where the leaders have designed policies and programs in the areas of good governance and the economy to ensure the realization of the millennium development goals (ECA, 2010).

The literature shows that public administration reforms enhanced best practices in some Africa countries. The best known example is Botswana, which is reputed for its good institutions, prudent macroeconomic management, political stability and efficient civil service. However, the lessons of experience have shown also some limitations of the SAPs of the 1980s, and have pointed to the need to broaden the agenda of public sector reforms. It is now being acknowledged that States with weak institutions are not well prepared to face the adjustment costs of globalization. Without complementarities between domestic strategies for institutional reform and strategies for opening up to global market forces, African countries risk exposing themselves to the kinds of protracted crises from which some have just begun to recover.

\section{METHODOLOGY}

The data for this study were collected in 2013 in ten months period from September-June. Senior public administration students were involved in the data collection process. As part of their senior research project the students were advised to conduct research on public administration reform in Eritrea with a focus on civil service, public enterprises management and local government administration. This study used primary and secondary data sources. First, it reviews the literature on public and civil service reforms globally and in Africa to assess the trends, processes and challenges of administrative reform. Secondly, the paper draws on documentary sources such as the constitution, proclamations, and government and UN publications and reports, which give official views of reform initiatives and processes. Thirdly, we conducted interviews with 50 key government officials (15 public enterprises managers, 20 top level civil servants and 15 local government administrators). The interviews were carried out to help analyze the outcomes of the reform efforts of the government. It is always advisable to accompany secondary data with some in-depth interviews, even if time permits only a limited sample (Gobo, 2004; Soeters and Nijhuis, 1988). The rationale for using multiple sources of data is the triangulation of evidence. Triangulation increases the reliability of the data and the process of gathering. Ghauri and Gronhaug (2002: 181) defined triangulation as "the combination of methodologies in the study of the same phenomena". Triangulation compares the results from either two or more different methods of data collection (for example, interviews and observation) or, more simply, two or more data sources (for example, interviews with members of different interest groups). Triangulation helps the researcher to develop patterns of convergence or to corroborate an overall interpretation. Triangulation is better seen as a way of ensuring comprehensiveness and encouraging a more flexible analysis of the data.

To check the reliability of data and information we have asked similar questions to government officials at different levels. As a further proof of reliability we have asked also similar questions to the same informants at different times. Thus we have designed the interview questions to support the reliability and objectivity of the data collected. Through such method qualitative data was collected both from primary and secondary sources on the three vehicles of public administration: civil service, public enterprises and local government. Qualitative data helps the researcher to obtain detailed information about the case under investigation.

In this study, public administration is defined as the aggregate machinery (policies, rules, procedures, systems, organizational structures, personnel, etc.) funded by the state budget and in charge of the management and direction of the affairs of the executive government (UNDP, 2004:1). Administrative reform is seen as a deliberate plan to change public bureaucracies and organizational structures, with the aim of improving the capacity of institutions to make policy and deliver services in an efficient, effective and accountable manner (ADB, 2005; Cited in ECA, 2010:5). In this paper, civil service is used to describe two sets of ideas, namely, (i) it refers to the body of permanent officials appointed to assist the political executive in formulating and implementing governmental policies, who are referred to as civil servants; and (ii) it refers to ministries and departments within which specific aspects of government work are carried out (Adamolekun, 1999, cited in ECA, 2010:4).

\section{Limitations of the study}

This research can be considered to be the first exploratory research into public administration reform in Eritrea. Owing to the sensitive nature of the topic, the author refrained from asking personal questions pertaining to age, education, salary, rank, party affiliation, place of work, and type of work. Therefore, the author was unable to link the characteristics of individuals or groups of civil servants, local government officials and public enterprise mangers. The data analysis was done at an aggregate level. The collected data was also a qualitative nature, hence not convenient for descriptive (statistical) analysis.

\section{ANALYSIS OF THE RESULT OF PUBLIC ADMINISTRATION REFORM IN ERITREA}

In most African countries, the transition to independence was smooth, and administrative institutions continued to be run on the bureaucratic principles and practices that had been introduced under colonial rule. However, in Eritrea the transition to independence was not smooth; Eritrea gained its independence from Ethiopia after 30 years of bloody war. The bureaucracy inherited from Ethiopia was inefficient and characterized by a corrupt nature of administrative infrastructures. Eritrea as a new nation faces a number of administrative problems requiring reform to meet the global needs and demands of the twenty first century. These problems were inherited from the Ethiopian colonial bureaucracy. The inherited colonial bureaucracy was inefficient and characterized by a corrupt nature of administrative infrastructures. It had many attributes that render it unsuitable for many challenges of the Eritrean government. It was filled by administrators without adequate professional qualifycations, excessively dependent on seniority rather than merit considerations with negative implication for moral and efficiency. It remains also both understaffed and overstaffed. It was significantly understaffed in professional and managerial areas and overstaffed in semi- 
skilled and unskilled areas. To rectify this the Eritrean government conducted a functional review of ministries in 1995, which has a number of outcomes: a reduction of the number of civil servants, higher pay for the remaining government employees, clarification of the roles of ministries, emphasize on increasing efficiency, a decision to privatize state owned enterprises and decentralization to regions. But there are a number of challenges remaining: these are educational capacity development gap, many ministries are devoid of modern planning tools and many community leaders are, in general, due to educational gap and unfamiliarity, not in a position to lead the needed transformation and to take charge of the subsequent change in working procedures the new technology require and induce (United Nations, 2001:25).

The Eritrea government has adopted also new policies to recover the war-ravaged economy based on selfreliance, technological transfer and private investment to stimulate economic growth and flow of foreign capital. Besides the task of economic recovery the creation of democratic institutions and secular government is one of the nation's priorities. The leaders of the newly independent state are confronted with formidable challenges. Prominent among these were promoting accelerated socio-economic development, fostering national identity which requires welding together the multi-ethnic and multi-religious entities, and creating the structure of governance, in particular public service which has the commitment and competence to support and facilitate the task of nation building.

\section{Civil service reform}

Civil Service Reform programs have increasingly been adopted in Africa often linked to structural adjustment efforts. The purpose is to improve the effectiveness and performance of the civil service and to ensure its affordability and sustainability over time. The ultimate goal is to raise the quality of public services delivered to the population, and to enhance their capacity to carry out core government functions.

Eritrea, just like most developing countries, introduced civil service reforms (1995-1997) that led to (1) streamlining of about 34 per cent of the Eritrean civil servants (UOA, 1997); (2) the establishment of the Eritrean Institute of Management (EIM) in 1995; (3) the introduction of a new salary scale in 1997; and (4) the launching of the Eritrean HRD Project (1998-2003) (EHRDP, 2003). The key elements of the process of reform of the civil service in Eritrea have been centered around pay and employment measures; productivity enhancement; capacity building; training; improving accountability and transparency; and making management more effective.

The Eritrean government undertook civil service reforms in two phases: 1995-1996 (first phase) and 1997 (second phase). The central objective of the reforms was to create an Eritrean civil service that possesses attributes such as: a lean, efficient, well-paid, well motivated, well managed, and well trained public service (Gafer, 1996:1). The civil service has undergone very extensive restructuring both functionally and organizationally. Because of restructuring and streamlining Eritrean civil service staff positions reduced by $34 \%$, down to 18,500 employees from over 30,000 employees ${ }^{3}$ (Tessema, 2005).

Currently, in Eritrea three new concerns are needed to civil service reform efforts. These are public expenditure management, institutional reorganization, and strengthening of policy analytic capacity. The civil service improvement activities falling under the category of public expenditure management include budgetary management, management of public investment programs, external debt management, auditing, tax administration and procurement. The institutional re-organization activities consisted of employment reduction and growth control, reviewing of salary and compensation policies, job classification and evaluation, documentation and records management, and personnel management. Among these groups of activities, the employment reduction mechanisms such as elimination of "ghost" workers, retrenchment, and voluntary departure, attrition through hiring freeze and enforced retirement had been intensively adopted; and thus resulted in a reduction in the size of the civil service. Enhancing the policy analytic capacity of the civil service is the third important area, which took form the renewed emphasis of the government on professionalization of the civil servants and community leaders in the sense of equipping them the skills of policy implementation and evaluation of development programs.

Despite all the above civil service reform efforts, the environment within which Eritrean civil servants are employed does not seem to attract, motivate and retain competent civil servants (Tessema \& Soeters, 2006). Like most African countries Eritrea has acute shortages of qualified staff. It is a paradox of todays world that developing countries, like Eritrea, that have the greatest need of competent civil servants to economic and social development are losing many of their educated young men and women to the developed world. It is difficult to replace the knowledge, skills and experience of competent civil servants. These skills are only acquired over a long period of time and are accompanied by extensive experience. Eritrea today is experiencing a growing need for civil servants who are capable of efficiently, effectively and creatively mobilizing the available scarce resources to achieve national objectives

\footnotetext{
3 The vast majority of them were from lower positions such as janitors, receptions, guards, and typists. The streamlined civil servants were given six months salaries. Unlike in other African countries, it was not voluntary.
} 
(Tessema and Soeters, 2006).

\section{Public enterprise reform}

Public enterprises reform in Eritrea was driven by three main considerations, namely: to increase their efficiency; reduce the twin burdens of fiscal deficits and external debt to which the public enterprises were contributory; and to stimulate an expansion of competition in the economy by reducing the monopoly powers of some public enterprises. These reforms evolved along two interrelated paths. One centered on privatization programs which involves share of shares, assets or outright closure. The other focused on improving the performance of enterprises retained under state control which included such measures as management contracts, contract plans, improving the macro-economic environment, and rationalizing institutions for public enterprises control and commercialization which forced public enterprises to face hard budget constraints.

The Eritrean government initiated its reform program by classifying public enterprises into three main categories: strategic enterprises slated to remain in the state portfolio; commercially viable enterprises to be privatize; and non-viable commercially oriented enterprises slated for liquidation. The key challenge for Eritrea is to find an optimal size of public and private sectors in a mixed economy that will promote both ends of the spectrum and approximate, or even satisfy the broad general public interest, and not particular powerful elites. The management of public enterprises faces formidable challenges of maximizing internal efficiency, which is characteristics of the market, on the one hand, and upholding the equity and politics of the government on the other; this involves an interaction of politics and market (Farazmand, 1996). In practice, achieving the dual economic and political goals has not been easy.

\section{Privatization}

The term privatization is defined in various ways, connoting different things for different people. In this study privatization is defined both in its narrow and broad meaning. In its narrow meaning, it simply entails a shift of productive activities or services being undertaken by the public sector to private ownership or control. In its broader meaning, it refers to a process by which the state's role within the economy is circumscribed while at the same time the scope for the operation of private capital is deliberately extended (Young, 1991:50).

Eritrea has opted for an open, private sector led, free market economy. The Eritrean Government, as stated in its macro-policy (1994), is aiming at developing a capital and knowledge intensive and export-oriented manufacturing sector as part of its socio-economic transformation. The government has been taking necessary policy and other supportive measures to promote, encourage and develop the private sector and to protect its interests (Stifanos, 2001). Based on its free market policy, the Government of Eritrea returned nationalized housing residents and other buildings to their owners. The government privatized also 700 small-scale shops.

To privatize medium and large scale public enterprises the government issued proclamation No. 83/1995 for the establishment of the National Agency for the Supervision and Privatization of Public Enterprises (NASPPE). The objectives of NASPPE as stated in GOE (1995:4) are "to privatize public enterprises and until such events, implement an appropriate management policy, function, duties to vitalize, optimize and transform productivity and establish a competitive and conducive economic ambience in all public enterprises for and in the enhancement of their privatization". In 1996, NASPPE divided the 46 state-owned enterprises into three groups: (1) those that are retained by the state as strategic industries; (2) those that are assigned to the Eritrean People Front for Democracy and Justice (EPFDJ the ruling political party); (3) those that are offered for domestic as well as foreign buyers publicly; and (4) those that are liquidated.

The government retained four strategic enterprises [Red Sea Flourmills, Dekemhare Flourmills, BarkaCanneris and Dogali Printing Press]. The government also assigned a printing press [Adulis Printing Press] to EPFDJ. Two public enterprises were liquidated [Denden Glass Works and Ethiopian Domestic Distribution Corporation]. The remaining 39 public enterprises were slated for privatization.

As in many African countries, the record of privatisation and commercialisation in Eritrea has been patchy, slow and modest. Out of the 39 stated owned enterprises lined up for sale only 18 were privatized during the period 1996 to 1999 . The sales of the remaining 21 enterprises have not yet realized. Absence of capital markets, in Eritrea, is a major obstacle for the privatization plans.

The privatization process, in Eritrea, takes a long time, and destroys the value creation potential of the companies. It affects enterprises' working and fixed capital investments, and financing. A long privatization process hinders innovations, plans and investments. This phenomenon was labeled by Stifanos (2001) as "privatization trap". The privatization process did not vest a complete and real authority upon managers rather it creates uncertainty and confusion. The managers and the employees are uncertain about their position and their fate after the sale of the companies. Privatization in its very beginning accompanied by layoffs, more often it is not a good means of job creation because most of the public enterprises are over staffed. This would raise the growing number of unemployment until potential investors create 
a job opportunity for the local people (Farazmand, 1996).

Striking a balance between privatization and retention of public enterprises is a major challenge for many African countries. Few countries in Africa, such as Ghana, Zambia and Uganda have vigorously pursued privatisation, while a majority of the countries including Senegal, Tunisia, Benin, Côte d'Ivoire, Togo, Cameroon, Kenya, Guinea and Nigeria have either made modest or limited progress, or reversed privatisation policies at periodic intervals (Lalaye, 1999). Other countries such as South Africa, Zimbabwe and Tanzania have remained strongly tied to public ownership. They have therefore taken limited steps towards privatization and commercialization because of their leaders' strong attachment to state capitalism.

\section{Local government reform}

Following their independence in the early 1960s most African countries supported the idea of a strong central government to secure social justice for all citizens and Eritrea was not an exception. The new regimes and central governments were considered as facilitators of wealth distribution. Politically, the one-party system was portrayed as an embodiment of the people's will and a way of uniting the new nation (ECA, 2003). In the 1990s, however, domestic and external forces started to exert considerable pressure on African governments to liberalize the political space. Consequently, democratic systems were introduced, which embarked upon ambitious program of political, institutional and economic reforms. The objectives of those reforms, along other things, involved restructuring and decentralization. Decentralization of responsibilities in its various forms is advocated as a means of achieving public service effectiveness and ensuring that public administrations are more responsive to citizens' needs. To strengthen the capacity of decentralized agencies, substantive measures have been recommended (ECA, 2003:54):

1. Delegation of authority in respect of finance and personnel management to managers at lower levels within the framework of broad guidelines from the center to strengthen field administration, and laterally from policy making units to implementing organs;

2. Empowerment of communities by strengthening local governments through the revitalization of local authorities and municipal governments;

3. Mechanisms for full participation of the private sector and civil society organizations in public policy formulation and decision-making should be established in order to improve local democracy, accountability, efficiency, equity, effectiveness and sustainability in the provision of social services countrywide; and

4. Providing civic training on rights and obligations (in local languages).

In view of the above context, local government reform in Eritrea was driven by restructuring, decentralization, and accountability measures. The aims of these reforms were to stimulate participation at the grassroots level through devolution and de-concentration. The Eritrean people want the state and its public administration to act as a social and economic promoter, capable of ensuring equitable distribution of opportunities, sustainable management of resources and equitable access to opportunities (political, economic, social and cultural) (GOE, 1993).

\section{Restructuring}

Restructuring involves the redesigning of the structure of organizations to improve effectiveness and efficiency. Restructuring devices include eliminating red tape, downsizing, decentralizing authority, and improving organizational effectiveness through privatization, commercialization, partnerships and coproduction (Ayee, 2008). The reform agenda usually includes an attempt to address the rigidities and dysfunctions associated with mechanical structures, a process referred to as 'debureaucratization' (Turner and Hulme, 1997; Caiden, 1978, 1991; cited in Ayee, 2008).

Eritrea inherited obsolete institutions and weak instruments for managing its economic policies. While it was part of Ethiopia, and in the context of the centrally planned economy, the provincial administration in Eritrea had little autonomy and policy making capability. The Eritrean government reformed the inherited administrative system by issuing proclamation No. 37/1993 that defines the powers and responsibilities of the local government units, and establishment of the Ministry of Local Government. The National Assembly entrusted the Ministry of Local Government to undertake the task of redrawing the boundaries of the 10 inherited regions. With this mandate a committee, from the various government agencies, for the restructuring of the regions was established. As a result, the 10 provinces, 50 sub-provinces, 194 districts and 2580 villages were restructured into 6 administrative zones (zobas), 58 sub-zone (sub-zoba), and 699-village/ area administrations. To this effect the government of Eritrea issued Proclamation No. 86/96 announcing the establishment of six administrative zones (zobas) in Eritrea. The six administrative zones (zobas) are: DebubawiKeih-Bahri, Gash-Barka, Maekel, SemenawiKeih-Bahri, Anseba, and Debub. The main objectives for undertaking the restructuring program were: to minimize the levels of administrative tiers vertically and horizontally and speed up the process of decentralized administration and devolution of authorities, ensuring democracy and sustainable development, 
throughout the country; to bolster equitable economic growth; and to strengthen the unity of the people.

Proclamation No. 86/96, gives way for the establishment of four layers of government in Eritrea: Central, Regional, Sub-Regional, and Village/ Area Administration. The regional and town administrations are composed of the legislative council (Baito), executive, and judiciary bodies, while the village/area administrations have a general assembly (Megaba'aya) constituting all residents above 18 , in addition to the executive and judiciary. The public administration structure of the Eritrean urban towns includes legislative, executive, and judiciary branches. The purpose for a three-part division system is the prevention of abuse of power by any single branch (Proclamation No., 23/1992). Each town, thus, shall have the Legislative (Baito), Executive and the Judiciary. The Executive organ of each Region is made up of: a) Governor, b) Executive Director, c) Line Departments and Staff Function Heads, and the Executive organ of towns is composed of: a) Town Administrator, b) Executive Director, c) Line Departments and Staff Function Heads.

The executive bodies are made up of a mayor, a deputy mayor and various functional units. They are part of the municipal local government, responsible for executing administrative services and other routing and developmental and reconstruction activities, on behalf of the councils. The municipal chief executive is appointed by the government, and the structure is operating under the Ministry of Local Government. Among the major tasks of local executives is to co-ordinate and supervise the overall planning, program identification, implementation, and management processes taking place at the local level in collaboration with line ministries. Besides, they assist the local councils in the preparation of development plans and budgets and allocation of central government budgets.

The legislative body, namely Baito or 'council' is made of democratically elected community representatives. The regional council is made up of sub-regional representatives, and the sub-region council by village representatives, and the village council by community members eligible to vote i.e. over 18 years old. The number of Baito members or seats depends on the size of the area, the number of registered adults and composition of ethnic groups and sex. In Eritrea the regional assemblies are directly elected by the people while the governors are appointed. The practice of democratic election has a long-standing history. Local elections have been organized by local people in their villages and the practice continued during the struggle for independence. The voting systems in the villages are accomplished by direct show of hands and open debates. The council of elected village elders are traditionally in charge of organizing the Megaba'aya and rekindling people's participation in administering various socio-economic activities.

There is an elected chairperson and a secretary, who permanently represents the council and follows up routine activities and is supported by permanent and temporary committees. The committees are delegated to handle specific duties and responsibilities. The permanent committees are the functional committees who are responsible for legislating, financial management, agriculture, trade and industry, social affairs, health, education, culture, information and construction. Temporary committees are also established for accomplishing specific assignments such as arranging ceremonial celebrations, etc.

The councils are the highest decision-making organs responsible for policy formulation, implementation, monitoring and evaluation. As legislative bodies, they are responsible for legislating and monitoring the performance of their constituent executive bodies such as municipalities and town administrators and heads of functional units. Along with the responsibility for approving budgets the Baitos are empowered to levy taxes. They are also responsible for approving submitted projects programmes and related budgetary plans. It reviews reports, evaluations of the executive and accordingly makes its own suggestions and views. If any objection is raised, it sends its findings with its objectives and reservations together with its recommendations to the Ministry of Local Government.

The judiciary, consisting of the various courts will safeguard the individual, collective and governmental rights, liberties and properties guaranteed by law. The judicial branch functions independently of both the legislative and executive branches (Proclamation No. 23/1992).

In Eritrea urban areas are classified into three categories depending on the area they administer. The lowest urban centre in Eritrea is presumed to have at least 5 Baito (Legislative council) members. By the same token this particular urban centre should have a population of 5000 to 10,000 because a population of 1,000 to 2,000 is represented by a Baito member. The town and urban councils have been graded by the Ministry of Local Government. The Grading Criteria, among others, were:

1. Population - population density and distribution;

2. Economic Development - gross domestic product, cash crops, food crops, other economic activities such as industries, public corporations etc.

3. Economic Infrastructure - roads (paved and unpaved), district roads vital for agricultural procedure and other commodities, post and telecommunications.

4. Social Services - education (number of schools, pupils and other facilities), health, water, water facilities etc.

5. Revenue Generating Capacity - the numerical weight given to the revenue generating capacity is based on collective and subjective judgement.

The central government defined the general principles of 
municipal administration by way of national legislation. These include defining the general and specific mandates of local government, tax legislation, and state supervision, under which local authorities carry out their functions.

\section{Decentralization}

The concept of decentralization defies a clear-cut definition. Rondinelli (1989) defines decentralization as the transfer of authority to plan, make decisions and manage public functions from a higher level of government to any individual, organization or agency at a lower level. To Smith (1985:1), decentralization means 'reversing the concentration of administration at a single center and conferring powers on local government'. In this study, decentralization is considered the opposite of centralization or concentration, and involves delegation of power or authority from central government to the periphery.

The Government of Eritrea has adopted administrative decentralization as a national policy in May 1996. In an interview, in 2013, higher government officials in the Ministry of Local Government stated that the very essence of decentralization, in Eritrea, is to increase the space for decision-making at the local level for the local people, so that government officials will be more responsive to local needs and thus more effective and efficient in the provision social/public services. Delegating responsibility to local governments can influence also the incentives for competition between jurisdictions to provide improved public goods.

Decentralization and devolution of power has been pursued in Eritrea for the last ten years (1997-2006). While considerable achievements can be noted for Southern Administrative Zone and Gash-Bark, human resource and material limitations and the conflict with Ethiopia have hampered progress in other regions. Decentralization helps the local people to resolve their social problems through personal contact with local leaders. Local workers are better able to identify problems and opportunities, more likely to use area -and culturespecific solutions and better able to match supply decisions to local situations. The nature of the social environment within which such spaces for local discretion are created is thus likely to be a critically important factor in the realization of the policy vision of the Eritrean government.

According to the Regional Administrations Proclamations No.86/1996, generally recognised municipal functions have been specified which include the following:

1. Upon approval levy and collect urban land rent, service charges and urban house tax charges.

2. Enforce laws pertaining to the administration of the urban centres, the security of the urban centre and the health of the urban dwellers.
3. Prepare and submit to the local government and when approved implement the master plan of the urban centre and administer urban land in accordance with the approved plan.

4. Without prejudice to the power given by law to other government offices, organise, prepare, maintain streets, squares, bridges, utilities as water, electric light, grand market place, cemeteries, abattoirs, drainage systems, public baths, theatres and public halls, schools and the like.

1. In co-operation with appropriate central government offices: ensure the provision of adequate transport services, operate and co-ordinate social service programmes, ensure and supervise the orderly construction according to plan of water pipe lines, sewerage system and houses.

2. Organise and provide fire-fighting ambulance, and sanitary services.

3. Ascertain that any work done by or under any family, individual or organisation is not contrary to the requirement of public health and safety; and issue permits thereof.

4. Designate the location of the livestock-marketing centre within the urban centre and issue administrative directives for the centre.

5. Take appropriate measures to ensure the cleanliness of the urban centre and the health of the urban dwellers.

6 . Determine the width, property, and manner of construction of any new urban road.

7. Establish a judicial tribunal.

8. Collect charges, rents, taxes and fees due to municipality under various laws previously in force, implement powers and duties conferred on municipalities under various laws previously in force in so far as they are not inconsistent herewith and the government ownership of land.

All of these functions are assigned to local authorities, although, understandably, the smallest municipalities are unable to perform these duties on their own. Hence, the proclamation reserves the following responsibilities to the central government bodies. These include:

1. Responsibilities related to defence and national security, citizenship, immigration, issuance of passports, protection of refugees, and expulsion and extradition;

2. Foreign affairs, national economic policies, justice and general auditing;

3. Establishment and administration of institutions of national significance and banking and banking-related activities;

4. Issues related to national parks (land and sea), museums and historical preservation, national holidays, working days and hours.

In Eritrea, however, central authorities regularly excuse 
continued involvement in local level provision because of capacity limitations at local government level. They argued that financial management, project implementation, construction and planning have to be centralized because of poor capacity. Decentralization requires local level managerial and technical capacity, particularly planning, operations and maintenance (Andrews and Schroeder, 2003). Lack of technical and managerial competence, and human resource capacity constraints are the major limit to the planned decentralization process in Eritrea. In the health sector, for instance, there are acute shortages of indispensable staff for planning, management and operation of health facilities at the local levels. There are shortages of surgeons, health laboratory technicians, midwives, and experienced administrative personnel with good planning and management practices.

A second aspect of capacity involves institutional abilities for intergovernmental coordination. In functional areas, in Eritrea, there are clear pictures of deficits; coordination, cooperation and information sharing between ministries are often based on informal networks and initiatives of gifted individuals (UN, 2001). Long-term planning and more importantly, prioritization within Eritrea institutions are a problem despite concerted efforts by the government in this area.

A third aspect of capacity pertains to fiscal management. Effective decentralized service provision requires an adequate level of local governance, including legal and financial capacity (Peterson, 1997). This requirement extends to both monetary resources, i.e. a fiscal base sufficient to ensure funding for maintenance and operations, and personnel and processes, i.e. appropriate staff and systems for managing the money. Where these capacities are limited locally, fiscal management tends to be centralized. In most African countries the absence of fiscal decentralization is a constraint for effective provision of public services. Local governments do not reallocate funds between sectors or retain revenues collected from public services. Centralized decisionmaking over the allocation of financial resources made local governments heavily dependent on the center. If local authorities do not have financial control for their activities, they cannot be flexible enough to cope with the emerging needs or problems of the population of their jurisdiction. In developing countries like Eritrea, there is a need for legislation that requires the decentralization of central budgets and the devolution of some fiscal authority.

Decentralization within the context of a unitary state is beneficial for Eritrea. Decentralization will make local administrators more responsible and quick to respond to local needs. Decentralization, however, cannot be created or accelerated by policy decisions alone, it will instead evolve over time as regions, local economies and cultures transform themselves (Rweyemamu, 1982).

\section{Accountability}

Accountability is one of the most important objectives of administrative reforms. In the words of Paul (1992, cited in Ayee, 2008), accountability is the 'driving force that generates the pressure for key actors involved to be responsible for and to ensure good public service performance'. It involves not only tackling corruption, but also improving public sector performance, effectiveness, efficiency, achievement of goals, probity and regularity on the part of public officials who are expected to follow formal rules and regulations (Ayee, 2008). Rondinelli (1989) further noted that it is through open, transparent and accountable government that we are able to distribute power and influence so that no one institution, no one organization or no one individual can dominate the public agenda. A range of institutions has been created to promote accountability, including auditors and ombudspersons. A key question remains: to whom is the public servant accountable? (Paul, 1992, cited in Ayee, 2008).

For a government bureaucracy to be accountable to its citizens, provisions must be made for the citizens to control and monitor the use of discretionary power by bureaucrats. Accountability therefore, implies that citizens have certain new democratic rights. This new set of values include: the right to a clean and honest government; the right to high quality public services and products; the right to question and appeal against bureaucrat's decisions and rulings; the right to know what government officials are doing; the right to self government especially at the local level; and the right to remove a bad government official. In other words, a government bureaucracy that is accountable is one that is uncorrupted, efficient, transparent and open, decentralized and removable, therefore, temporal (Bowornwathana, 1996;7).

In developing countries like Eritrea, weak public institutions and lack of capacity to manage development were acknowledged as causes of lack of economic progress and accountability. To this end a number of administrative problems requiring reform became apparent in Eritrea in the early 1990s. These problems were rigid structures, and hierarchical organization, recruitment of generalists in to the administrative service, and a system of promotion based on seniority rather than merit, remuneration being out of line with prevailing levels in the private sector and lack of job evaluation, poor intra- and inter-sectoral mobility, weak administrative leadership, over centralization, poor staff development and training arrangements, anachronistic administrative management practices and lack of effective coordination.

\section{DISCUSSION}

In an interview, in 2013, almost all civil servant officials stated that delay in the enactment of civil service laws, 
absence of promotion, retirement, and salary increment are the major problems of the Eritrean civil service system. Because of that recruitment and promotion systems overly concerned with formal education, and fail to attract or promote qualified staff. Politicization of the civil service is another problem. Erosion and compression of salary scales are also claimed to be the two major contributions to bureaucratic corruption. Most of the civil servants, interviewed, recommend for the review of compensation system in Eritrea, to ensure that salary levels and working conditions reflect market scarcities, cost of living and the productivity of each unit of government. Emphasizing on the importance of pay, in an interview in 2013, a civil service officer also stated that those that manage public service employment must not lose sight of the fundamental relationship between pay, motivation and performance. In poor countries like Eritrea pay plays a great role in public employees' motivation. There are reports that many countries, including the Gambia and Guinea, have made considerable progress in simplifying their grading structures (Hope, 2002). This, in turn, has acted as a magnet to attract and motivate some top professionals including those with scarce skills such as physicians and accountants. The reality in Eritrea, however, is that even the government has made tremendous efforts to improve living wages in public services, there remains the problem of paying competitive wages that will retain or attract the best staff. Despite reforms, salaries are still low in the Eritrean civil service system and are not able to retain professional staff, which has contributed to the "brain drain" that many African countries have been experiencing during independence. Significant increases in salaries to attract and retain wellskilled staff may, of course, affect resources for other service delivery inputs. How to improve public sector pay and the quantity of other inputs that are essential for efficient service delivery remains a challenge for Eritrea.

The public service should be an ethical institution as the protectors of the public interest. One of the major challenges that Eritrea faces is the maintenance of social values in the civil service system. Such values include integrity, honesty, dependability, helpfulness, impartiality, courteousness, commitment and fairness. These were the cardinal values of EPLF. Unfortunately, in most African societies, there is no system for reinforcing these values (Agere and Mendoza, 1999: 26). A key factor underlying the ineffectiveness of administrative and financial accountability systems is the endorsement of "wealth at all costs" by many African societies. Public office holders and public servants who do not appear to have "prospered" from occupying public positions are treated with scant respect in many African countries. This declining value tends to encourage inefficiency and misappropriation of public money.

Government accountability is a key issue in Eritrea. In an interview in 2013 a civil service officer said that "without a transparent and effective civil service, government business and service delivery to the public will be crippled and mired in dishonesty and graft. I am convinced that an efficient, transparent and accountable civil service should be the hallmark of our democratic transformation and development. The Eritrean people deserve nothing less". The argument is that all government agencies and organizations should develop a performance measures by clearly stating their objectives and the relationship between their inputs and outputs; workload and productivity; outcomes of products and services; service quality and customer satisfaction. The central theme of the argument is that the public needs to know what government organizations are doing and how their work is performing and government organizations need to understand for themselves how well they are performing their task and what the results are. In general transparency and customer satisfaction required objective published standards by which the public could judge whether government agencies were performing satisfactorily and even doing a good job (Caiden, 1998:3). Governments should enhance public reporting systems on the financial performance of government agencies. This involves providing information on the financial and managerial performance of public departments that enables the public to monitor and assess performance of government activities. The aim is to encourage dialogue so as to lead to improved service delivery. The IMF and other international bodies have developed a number of codes and standards that set out "good practices" in the areas of policy transparency, data dissemination and financial regulation, and supervision.

In the context of Eritrea's administrative reform, efforts to make public service agencies more accountable to the public should include the adoption of Citizens Charters. Citizens should be consulted about the level and quality of public services and, whenever possible, be given the choice of services. Citizens should also be informed about the level and quality of services they will receive, and they should have equal access to the services to which they are entitled. Moreover, they should be informed about how national departments and provincial administration are run, how much they cost and who is in charge. The citizens charter can be designed to raise the standard of public services and make them more responsive to their users (Butcher, 1997:55) and to encourage public servants to think about what they do in relation to how it affects their customers.

In an interview in 2013 almost all public enterprise managers complain of having to cop with excessive, rigid, time consuming and inappropriate bureaucratic procedures. They have contended that the civil service procedures are incompatible with commercial operations. Because of that they are not able to suspend, fire, or indeed sanction in any meaningful way their large and costly work force. Nor do they possess discretionary 
power on salary and benefits. They have neither sticks nor carrots. The Eritrean government should focus on the reform of the public sector itself besides privatization aimed at allowing public enterprises to operate more efficiently and effectively. This can be done through organizational development, more accounting, more efficient management practice, isolation of state owned corporations from the whims of politicians, management contract, worker incentives, shared savings, productivity councils, management service, operations research, improving the macro-environment, rationalizing institutions for public enterprises control, and special training programs tailored to the unique need of public enterprises. Aylen (1987:23) argues that the weakness of capital markets in developing countries is a major obstacle to plans for privatization for this reason alone, public enterprises seem more likely to grow in importance rather than decline. Significant stock markets exist only in few African cities such as Logos, Abidjan, Harare, and Nairobi. It is not realistic to suppose that direct foreign investment will compensate for failure of domestic equity markets. The western value concept of efficiency and the British approach to large-scale privatization are generally not applicable to developing countries with an underdeveloped and corrupt private sector itself in need of government support itself (Farazmand, 1996:40). In the LDCs and post conflict countries like Eritrea, underdeveloped private sectors require the public administration to play a major role in the delivery of services and the provision of much needed economic infrastructure.

Most local government officials, in an interview in 2013, stated that lack of managerial and technical capacity, absence of fiscal decentralization and budget constraints as their major problems. A major drawback with many decentralization initiatives is the lack of administrative capacity of the public administration at the local levels and the absence of accountability lines of this administration to the local people. For decentralized government to succeed there needs to be a center to enable it; thus attention must focus on, for example, fiscal transfer mechanisms; mechanisms for ensuring local level planning and budgeting; systems for monitoring and oversight linked to the budget; and appropriate human resource development systems. The Eritrean government should now emphasize on investment in developing human capital towards effective policy formulation, analysis, implementation and evaluation.

\section{Emerging challenges}

Although the efforts of the Government of Eritrea are encouraging and commendable some challenges are still remaining. The government has not yet enacted: civil service law; co-operative laws as well as legislations governing non-profit organizations all of which have an impact on public administration. The United Nations
Common Country Assessment Group (2001) has identified also many challenges that have to be addressed by Eritrea. These are: (1) delays in devolution of power; (2) shortage of skilled human resource in the public sector management; (3) inadequate systems, procedures and controlling mechanism in public sector management; (4) lack of access to information; (5) rigidity of internal structures, not necessarily reflecting the powers and function of individual ministries; (6) backlog on unmet needs due to the two year state of war with Ethiopia.

The delays in the devolution of power (decentralization) are associated with the particular circumstances of the country. Local government authorities are short of fiscal resources and trained manpower, which are qualified and experienced and the lack of awareness of the people to take charge of their own local affairs effectively. However, common factors to all of the key challenges are the lack of qualified personnel and material resources. After many years of colonization and deprivation, the education system in Eritrea is weak and is unable to supply the number of qualified persons needed to establish strong civil service and private institutions (UN, 2000). The UN report further added that due to the educational gap and the unfamiliarity many community leaders in Eritrea are not in a position to lead the needed transformation and to take charge of the subsequent change in working out procedures the new technology require and induce.

\section{Transitional challenges}

Eritrea is a country in transition: (a) a transition from a state dominated economic order to market based economic system; (b) a transition from colonial military regime to a just and democratic society; and (c) a transition from conflicts and strife to political reconciliation and economic rehabilitation. The transition from a state dominated economic order to market based economic system, however, is not without challenge. The transition to market economy had three main challenges to Eritrea, namely: providing an effective regulatory framework for efficient functioning of markets; reorienting the public service to be efficiency conscious with regard cost and time; and enhancing reliance on market mechanisms for the management of public organizations (Beyene and Otobo, 1994). The economic transition demands also difficult tradeoffs between the market, the sate and the international arena. Striking a balance between Eritrean national interests and the international economic community was also a challenge quite for some time (Ruth, 1995: 143).

The transition to democracy poses the challenges of creating or strengthening watchdog mechanisms-organizations for upholding accountability whether democratic, legal or professional, enhancing the institutions for checks and balances; and promoting the neutrality and professionalism of the civil service (Beyene and Otobo, 1994). As 
regards the transition from conflicts to reconciliation, the main challenges are instilling public trust in the discipline of law and order agencies; fostering policies that promote economic and social equity; and increasing opportunities for popular participation in decision-making (ibid.).

The formation of a 'constitutional state' is an important task for Eritrea. A constitutional state requires an in-depth overhaul of the judicial and administrative system and the taking into account of individual and group differences. The power and scope of authority between the different branches of the government such as the legislative, executive and judicial should be clearly defined and determining the principal means for exerting control over the bureaucracy from sources outside it. In other words, there must be constant control both by checks and balances within the government and through outside control. Various ways of control can be devised such as 'administrative law', which is designed to counteract arbitrary, malicious, capricious and erroneous bureaucratic decisions and to control biases, misuse of power, inadequacy of investigation, and incomplete action or refusal to act.

The other control mechanism is through the establishment of an independent press or through the interference of a special interest group. In most African countries the press is still far from being an effective corrective mechanism. It still suffers from lack of professionalism and political obstacles. But in the long-run independent and indigenous press will help the ordinary citizens to protect themselves from the mercy of officious and sometimes corrupt bureaucrats.

Another solution is through the use of the ombudsman office. The ombudsman is a Scandinavian institution for the observance of 'public administrators conduct'. It investigates all forms of illegal or improper conduct by an official; be an executive officer or even a judge. The citizen doesn't need legal council or advice nor does he/she need approval of a superior authority to have recourse to the ombudsman.

Bentil (2004) suggests also the declaration of a 'civil service week', which gives the public, the press and the government the opportunity for an open debate, and helps to define the kind of services the public really want and how those services can be effectively rendered. This system was used in Eritrea extensively; citizens forward their questions, comments or ideas to the president via the ministry of information. The president gave answers to all citizens' questions, which was broadcast by the television, at the month of September each year. Government officials also show up, more frequently, on the national television in order to justify government policies and actions.

\section{The challenges of war}

Eritrea's initial promising growth was disrupted by the sudden out break of the border war with Ethiopia in May 1998 and the continuation of the war until June $2000^{4}$. The war has reversed the positive economic trends of the pre-conflict post independence period of Eritrea. The prolonged conflict has had also devastating human and social impacts. As the result of the conflict over 70,000 Eritreans and Ethiopians of Eritrean origin have been forcibly deported from Ethiopia; about 1.1 million people were driven from their homes, the great majority women and children; over 250,000 men and women between 1840 were mobilized for national defense (GOE, 2001:13). They are workers, farmers, professionals, civil servants and business people, and are among the nation's most productive citizens. Many provide most of their family's income. This widespread mobilization is costly to the economy both in terms of direct costs, as the government provides subsistence to the soldiers and financial support to their families, and indirect costs due to the divers in of labor from productive activities to national defense.

The real cost to the nation, however, is not limited to financial and economic sacrifices. The separation of family members for long periods due to deportation, internal displacement and mobilization has created social and psychological scars that are deep and serious. Dependent children and the elderly are affected. No family has been spared from this tragedy, and the social and psychological impact of the trauma will take a long time to heal.

Before the outbreak of the war most of the transition issues had been addressed in Eritrea, investor confidence was beginning to grow, private investment in a number of sectors was increasing and the economy was growing rapidly. Significant progress has also shown in education and health. Primary and middle school enrolment increased from about 178,800 in 1991-92 to 370,000 in 2000 (GOE, 2001) and there was a sharp decline in infant and child mortality rates; under five mortality rate declined from 203 to 89 and infant mortality declined from 135 to 47 (per 1000 live births) during the period 1993 to 2002, respectively. No cases of polio or diphtheria have been reported since 1998 and all immunization diseases and malaria have declined.

\section{CONCLUSION AND POLICY IMPLICATIONS}

Introducing reform programs in the government administrative system is a complex process requiring support at the highest levels and great internal management confidence and skill. The more comprehensive the reform is,

\footnotetext{
4“"Eritrea and Ethiopia fought a destructive war during 1998-2000 in which 120,000 people perished from both sides. The war had an extremely painful economic and social impact and Eritrea's progress on the path of socioeconomic development suffered a major setback” (Desta, 2013).
} 
the more complex the process, the greater the management capacity required to implement it successfully. Administrative reform is a long-range process and requires careful planning and sustained action. It is a continuing task and implies a need for periodic review and improvement. Within this context we would like to forward the following remarks on Eritrea's Public Administration reform:

1. The environment within which Eritrean civil servants are employed does not seem to attract, motivate and retain competent civil servants. The civil service values are declining. Competitive wage structures have to be designed to retain and attract competent civil servants and to regain the societal values of civil service.

2. Decentralization requires local level managerial and technical capacity. Lack of competent staff at the local level is a major impediment in Eritrea. Decentralization cannot be created or accelerated by policy decisions alone, it will instead evolve over time as regions, local economies and cultures transform themselves and acquire the necessary kills and knowledge.

3. Performance measurement and evaluation of the public sector can be seen as critical to efforts to streamline governments; gain greater efficiency, productivity and effectiveness; enhance transparency and accountability; regain public trust in governmental institutions; and contribute to a reorientation of the role and functions of government. To this end, the Eritrean government should set up productivity units to monitor performance and render periodic reports to the executive, the legislature and the public.

4. Maintaining a balance between efficiency and equity is a formidable challenge for the management of public enterprises in Eritrea. Achievement of the dual economic and political goals is not easy. The government has to finding an optimal size of public and private sectors, in a mixed economy.

5. Capacity development in the Eritrean public administration system needs to be addressed at three levels: the individual level, the institutional level, and the societal level. Thus, the government should focus on human capital development, institution building and process improvement.

\section{Conflict of Interests}

The author have not declared any conflict of interests.

\section{REFERENCES}

Adamolekun L (1999). Public Administration in Africa: Main Issues and Selected Country Studies (Boulder, CO.: Westview).

ADB (2005). African Development Report 2005: Public Sector Management in Africa (Oxford/New York: African Development Bank).
Agere S, Mandaza I (1999). Enhancing Policy Development and Management in the Public Service. Commonwealth Secretariat, London.

Andrews M, Schroeder L (2003). Sectoral Decentralization and Intergovernmental Arrangements in Africa, Public Administration and Development, 23:1.

Ayee J (2008). Reforming the African Public Sector: Retrospect and Prospects (Dakar: CODESRIA).

Ayee J (2005). "Public Sector Management in Africa", African Development Bank Economic Research Working Paper, 82:1-56.

Bentil M (2004). 50 Years of Civil Service Reform Experience in Anglophone Africa: Reflection on the Past to Guide Future Efficiency in Governance (Accra: Design Solutions).

Beyene A, Otobo E (1994). "Public Administration in Africa: Past trends and emerging challenges", Afr. J. Public Adm. Manage. 3:2.

Bowornwathana B (1996). "Transforming Bureaucracies for the TwentyFirst Century: The New democratic Governance Paradigm", Paper presented at the $57^{\text {th }}$ National Conference of American Society for Public Administration, Atlanta, USA, June 29-July 3.

Butcher T (1997). 'Citizen's Charter: Creating a Customer - Orientated Civil Service', In: P. Barberis, Civil Service in an Era of Change, Dartmouth Publishing Company, Brookfield. U.S.A.

Caiden G (1998). "Approaches for measuring public sector performance in an era of rapid change", Paper delivered at public seminar held at the Institute of Social Studies, The Hague, June 10.

Caiden G (1978). 'Administrative Reform: A Prospectus', Inter. Rev. Administr. Sci. 44:106-120.

Caiden G (1991). Administrative Reform Comes of Age, New York: Walter de Gruyter.

Desta Y (2013). Applying a US Police Integrity Measurement Tool to the Eritrean Context: Perceptions of Top- Level Eritrean Police Officers Regarding Police Misconduct. Journal of organizational Transaction \& Social Change 10(3):328-261.

Dror Y (1976). 'Strategies for Administrative Reform' In: Leeman A. F. ed., The Management of Change, The Hague: Nijhoff Press.

ECA (2010). Innovations and Best Practices in Public Sector Reforms: The Case of Civil Service in Ghana, Kenya, Nigeria and South Africa.

ECA (2003). Public Sector Management Reforms in Africa (Addis Ababa: ECA).

Eritrean Human Resources Development Project (EHRDP) (2003). Terminal report and exit strategy. Asmara, Eritrea.

Farazmand A (1996). Public Enterprises Management Across Nations: Privatization or Reform? Implications for public Management Theory and Practice, Paper presented at the 57th National Conference of the American Society for Public Administration, June 29-July 3, Atlanta.

Frederickson G (1996). 'Comparing the Reinventing Government Movement with the New Public Administration', Public Adm. Rev. 53(3):214-29.

Gafer A (1996). The Role of the Civil Servant in the Development of Eritrea. Development Policy Management Forum (DPMF), 27p. http://books.google.com.ng/books/about/The_Role_of_the_Civil_Serv ant_in_the_Dev.html?id=zhjZHAAACAAJ\&redir_esc=y

Ghauri $\bar{P} N$, Gronhaug K (2002). Research Methods in Business Studies: A Practical Guide, Second Edition, Prentice Hall Europe.

GOE (1993). Proclamation for the establishment of the Ministry of Local Government. Gazette of Eritrean Laws Proclamation No. 37/1993. Asmara.

GOE (1995). The National Agency for the Supervision and Privatization of Public Enterprises. Proclamation No. 83/1995, Asmara, Eritrea.

GOE (2001). State of Eritrea: Transitional Economic Growth and Poverty Reduction Strategy (2001-2002). Asmara.

Gordon D (1992). African Politics. In: Gordon, April A. and Donald L. Gordon. Ed. (1992) Understanding contemporary Africa. Lynne Rienner Publishers, Inc, Boulder Colorado.

Hadas Eritrea (2002). A note taken from Eritrean National Statistics Office "Population studies". Tuesday 5 , November $2002,12^{\text {th }}$ year, No. 46.

Haregot S, Stanley J, Doctoroff M, Yosief G (1993). Public Sector Management Program for Eritrea: A Diagnostic. Asmara: United Nations Development Program. 
Hood C (1991). 'A Public Management for all Seasons', Public Adm. 69(1):3-19.

Hope K (1997). African political economy: contemporary issues in development. Armonk, NY: M.E. Sharpe.

Hope K (2001). Development policy and management in Africa.Gaborone: Center of Specialization in Public Administration and Management, University of Botswana.

Hope K (2002). ' e New Public Management - a Perspective From Africa', in McLaughlin et al, in New Public Management: Current Trends and Future Prospects, Routledge, London and New York.

Hope K, Chikulo BC (1999). Corruption and development in Africa: lessons from country case-studies. London: Macmillan.

Lalaye M (1999). 'Public Enterprises' In: Adamolekun L., ed., Public Administration in Africa: Main Issues and Selected Country Studies, Boulder, CO.: Westview, Ch. 3:28-48.

Larbi G (1999). The New Public Management Approach and Crisis States, Geneva: UN Research Institute for Social Development, UNRISD Discussion Paper No. 112.

Olaopa T (2009). Innovations and Best Practices in Public Sector Reforms: Ideas, Strategies and Conditions (Ibadan: University Press PLC).

Paul S (1992). 'Accountability in Public Service: Exit, Voice and Control', World Development, 20(7):1047-1061.

Peters B (1992). 'Government Reorganization: A Theoretical Analysis', Int. Political Sci. Rev. 13(2):199-217.

Peterson GE (1997). Decentralization in Latin America: Learning Through Experience. Washington DC: World Bank, Viewpoints. Latin American and Caribbean Studies Series.

Rondinelli D (1989). 'Analyzing Decentralization Policies in Developing Countries: A Political Economy Framework', Dev. Change 20:57-87.

Ruth I (1995). "The Eritrean Struggle for Independence", Great Britain, Cambridge University press.

Rweyemamu A (1982). "A decade of public Administration in Africa", Management and Administration series: No. 5, Kenya Literature Bureau.

http://books.google.com.ng/books/about/A_Decade_of_Public_Admin istration_in_Afr.html?id=HlbPngEACAAJ\&redir_esc=y

Soeters J, Nijhuis F (1988). "Measuring the quality of working life, using institutional and questionnaire approaches." In S. Tyson, K. F. Ackermann, $\mathrm{M}$.

Smith B (1985). Decentralization: The Territorial Dimension of the State, London: Allen and Unwin.

Stifanos H (2001). Corporate Value Creation, Governance and Privatization: Restructuring and Managing Enterprises in Transition, The Case of Eritrea. Ph.D. Thesis, University of Groningen.
Tessema M (2005). Practices, Challenges and Prospects of HRM in Developing Countries: The Case of Eritrea, Ph.D. Thesis, Tilburg University.

Tessema M, Soeters J (2006). Challenges and prospects of HRM in developing countries: testing the HRM-performance link in the Eritrean civil servicelnt. J. Human Res. Manage. 17(1):86-105.

Turner M, Hulme D (1997). Governance, Administration and Development: Making the State Work, New York: Palgrave.

UN (2001). Eritrea Common Country Assessment" Volume 1.

UNDP (1995). Public Sector Management, Governance and Sustainable Human Development,New York: UNDP.

UNDP (1997). Governance for Sustainable Growth and Equity, New York: UNDP

UNDP (2002). United Nations Development Assistance Framework for Eritrea: 2002-2006. Eritrea: Asmara.

UNDP (2009).

Report.www.hdrstats.undp.org/en/countries/profiles//ERI.html [accessed 15 June 2010].

UNICEF (2004). The State of the World's Children.

University of Asmara (UOA) (1997). Implementation Plan of the Eritrean Human Resource Development Project. Asmara: University of Asmara.

Van de Walle $N$ (2001). African Economies and the Politics of Permanent Crisis (New York: Cambridge University Press).

Walsh K (1995). Public Services and Market Mechanisms: Competition, Contracting and the New Public Management, London: Macmillan.

World Bank (1999). The World Bank Annual Report 1999 (Washington, DC: World Bank).

World Bank (2002). World Development Report. New York, Oxford University Press.

World Bank (2010). Making Services Work for Poor People, World Development Report 2004, New York: Oxford University Press.

World Bank (2000). Reforming Public Institutions and Strengthening Governance: The world Bank Strategy. Oxford. The World Bank.

Young R (1991). 'Privatization in Africa', Rev. Afr. Pol. Econ. 51:50-62. 